\title{
Blended Learning in Higher Education: A Study of Its Impact on Students' Performance
}

https://doi.org/10.3991/ijet.v16i14.23775

\author{
Najeh Rajeh Alsalhi ( ${ }^{\varpi}$, Mohd. Elmagzoub Eltahir, Sami Al-Qatawneh, \\ Nadia Ouakli, Hanine Bou Antoun, Atef F. I. Abdelkader, \\ Laith Al Jumaili \\ Nonlinear Dynamics Research Center (NDRC), Ajman University, Ajman, UAE \\ n.alsalhi@ajman.ac.ae
}

\begin{abstract}
The key goal of the paper is to study the influence of blended learning on the academic performance of students of a statistics Bluman course at the University of Ajman. The study designe was quasi-experimental. The study sampled 268 students divided into two an experimental group $(\mathrm{n}=135)$ that used blended learning; and a control group $(n=133)$ taught by the traditional method. The researchers prepared the achievement test as a tool of study after verifying its validity and reliability. The findings indicated significant statistical differences among the mean scores on the students' post-test in the two study groups. This is in favor of experimental group, educated using blended learning. Furthermore, in the results, the scores of the experimental group students were diverse based on the variable of gender (in favor of females), and according to the students' academic year (supporting those students in the fourth academic year). However, there were no statistically significant differences among the students according to the variable of the college in which they studied. The study recommends that mixed learning is to be employed more broadly to include various educational fields.
\end{abstract}

Keywords - Blended learning, traditional learning, a statistics course, academic performance, higher education

\section{$1 \quad$ Introduction}

Education plays a vital part in the progress of countries and cultures, so any country in the world striv es to improve its educational system. As a result, educational institutions are on the lookout for high-quality curricula and teaching methods that result in engaged and positive students to enable new generations to solve real problems in their societies [1]. Teachers are motivated to achieve those instructional results by combining traditional curriculum with e-learning, which includes a variety of models as well as technical and electronic advances both within and outside the classroom [2]. This approach emphasized the use of two modes of curriculum, formal and e-learning simultaneously. In the 21st century, there are various developments in entire aspects of life, including education. Instead of simply transferring knowledge, 
the focus in the education field has shifted to constructive learning for pupils, which indicates consentrating on the findings of education quality, closely linked with the aims of constructivist philosophy of teaching and learning. The learner constructs his understanding through social contact with others and the world, according to constructivist theory, and based on previous knowledge and experience [3, 4]. A series of constructivist learning techniques has arisen to achieve the goals of constructivist philosophy, which connects technology to learning in conjunction with constructivism and summon up the cooperative, collective learning and social engagement in where learners develop their knowledge [5]. As a result, the blended learning theory comes out. Blended learning is an expansion to classroom instruction over the internet that offers educational facilities with cutting-edge instructional practices and techniques to overcome the problems they face, as well as novel learning opportunities [6, 7]. Many researchers arguesd that the integrated learning is a natural progression of e-learning. E-learning is a combination of electronic learning and traditional face-to-face classroom learning. This combination makes a single learning model to reap the rewards and advantages of both when achieving the desired goals [8-16]. Moreover, blended learning is a type of e-learning where e-learning is incorporated and combined in one system with conventional learning. In this form, e-learning tools, Lessons, seminars, and training workshops are mostly held in actual classrooms with internet access, whether computer-based or network-based [17-19]. Additionally, Blended learning, accoding to [20], is the extensive use of media in electronic teaching in conjunction with conventional teaching approaches. According to [19], mixed learning is important in developing instructional systems that include the prepared scientific subject material, a web-based mentor, lectures, conferences, and live online sessions with teachers by combining the strengths of traditional teacher-centered learning benfiting from information technology (IT). According to [21], In comparison to the instructional curricula, the teacher and the learner are the key elements. To achieve correct blended learning, the instructor ought to be capable of using digital teaching methods, and students ought to be able to use technology such as laptops, the internet, and email, which assist translate this education to schoolrooms. Blended curriculum is a successful emerging approach for university education in terms of preparing students for lifelong learning. Since college education attemps to improve analytical and innovative thinking skills. It also aaims to provide students with methods of producing awareness, this has the effect of assisting students' education and enriching their information [22-25]. Moreover, [26, 27]found out that in the education industry, mixed learning can be applied using a variety of models. The models are shown in Figure 1. 
Model 1: Fully online curriculum with options for face-to-face instruction

Model 2: Mostly or fully online curriculum with some time required in either the classroom or computer lab

Model 3: Mostly or fully online curriculum with students meeting daily in the classroom or computer lab

Model 4: Classroom instruction with substantial required online components that extend beyond the classroom and/or the school day

Model 5: Classroom instruction that includes online resources with limited or no requirements for students to be online

Fig. 1. Blended Learning Models

Via the computerization of education in the UAE educational institutions, elearning was extended to universities. This was accomplished by integrating new technical approaches, such as computer networks, into the educational environment, as well as the planning of classrooms and interactive labs, with the conventional system to enhance learning findings. Thus, a blended curriculum has been successfully applied in UAE faculties to aid the teaching process and accomplish educational objectives. Since these capabilities and resources are available in universities, any faculty affiliate makes use of their students. There is therefore value in considering the potential value of this approach. In [14], they indicated that various pre-studies have argued that mixed learning is becoming increasingly significant in teaching and learning, chiefly in universities. The American Society for Training and Development (ASTD) has assessed blended learning as one of the 10 best methods in the field of information and communication [6].

\subsection{Previous studies}

The importance of mixed learning in the educational environment has been illustrated in several reports. Previous findings have demonstrated the effectiveness of integrated learning, causing the attainment of multiple educational advantages in cognitive, behavioral, psychomotor, and emotional abilities, according to the study of previous studies. In [23], He mentions that in blended learning, students will pause the lesson at any time and resume watching it later. Furthermore, students will watch the lesson several times over a period of time. According to[28], the activities and experiences, of schoolroom, content and the instructor inspire and empower learners to learn more intensely, resulting in a greater understanding of the intellectual content. Many researchers in these studies have focused on the impact on achievement as a dependent variable because of its significance in improving teaching methods and better reflecting the improvement of the learners" skills, talents, attitudes, and interest in 
learning. Both research works' findings showed that mixed learning has a significant effect on students' academic success. Several findings have shown that mixed learning improves academic performance, increases enthusiasm, and fosters optimistic attitudes toward mathematics and science learning. Among these studies are the following: a study conducted by $[29,30]$ confirmed the influences of blended learning on the middle school students' outcomes of in the southwest part of Tuekry. The findings showed that the mixed learning setting had generated a significant difference in students' academic achievement, to the benefit of the experimental group. Likewise [31] identified the impact of a blended learning on learning outcomes and skills of the scientific method in a course on a plant tissue culture at University of Nigeria Medan. Their results indicate that when opposed to the traditional learning approach, the mixed learning strategy was substantially more successful in improving students' academic accomplishment and knowledge process skills in the plant tissue culture course. Also, these findings are in line with those of [26], who compared the blended learning experience to a conventional learning environment in order to assess students' academic success. The results indicated that the averages of the final test grades of the experimental group students were higher than those of the control group students. Furthermore, another study conducted by [22]. They pointed the research aimed to see how the effect of blended learning on the German Jordanian University students in terms of achievement and desire when learning English. The results showed statistially signifiant achievement differences between the two groups; the expermental group outperformed the control subjects. Moreover, in the study conducted by [32]. The research aimed to see how a blended learning approach affected secondary school students' critical thinking, addressing the problem, science process skills, and science achievement. The results showed the positive effect of blended learning in the enhancement of critical thinking, addressing the problem, science process skills, and academic achievement of students. Such findings have been obtained in many studies [33-37, 5, 38]. The results assured the positive impact of blended learning on students' academic achievement. They also emphasized the importance of blended learning in terms of increasing enthusiasm and fostering optimistic attitudes toward mathematics, statistics, and science learning. These research have confirmed that integrated learning increased students' motivation to study and helped them cultivate optimistic attitudes toward mathematics and science. Nonetheless, the results did not corroborate the results carried out by [39], which aimed to show that instructors for mathematical and statistical courses generally feel that blended learning does not produce an effective teaching and learning process. The results from the t-test showed that examination marks of students instructed with blended learning were not significantly different from examination marks of students instructed using traditional teaching, which means that the traditional teaching instruction of 'chalk and talk' still has many proponents.

\subsection{The study problem}

One of the key challenges encountering the education sector nowadays, such as universities and schools, is using new technologies and information technology (IT) 
correctly in enhancing and developing the education system in these educational institutions. This is done by integrating this technology with learning and teaching processes. The researchers noted the students' weaknesses in academic achievement in the statistics course. This is explained on the basis of the fact that Students are disconnected from statistics, and they have little incentive or interest in learning it, contributing to their poor academic performance. The failure to use new teaching methods was associated with the integration of technology and IT, so it was hypothesized that the difficulty lies in the conventional teaching ways employed. The researchers, hence, approved the use of blended learning as a contemporary teaching method employing applications, multimedia, or quantifiable programs to teach concepts and allow students to engage with the material at their own pace. This helps to balance a classroom that contains students with different readiness, motivation, and skills to learn. Moreover, blended learning deviates from traditional teaching and memorizing of students. Hence, the research aimed to study the effect of blended learning on students' outcomes in a statistics course at Ajman University, as it is a compulsory studying term for the whole undergraduates of scientific faculties of Ajman University. Therefore, the existing study aims to probe the effect of blended learning on the academic performance of the statistics course of students at Ajman University by answering the following research questions:

1. Any substantial gap in mean post-test scores among the control and experimental groups of students?

2. Are there any differences between the academic performance of exthe perimental group, who learned the information by blended learning, according to sex, faculty, and student's academic year?

\subsection{Significance of the study}

- The researchers noted that there have only been a few studies focused on the blended learning effect on the academic outcomes in higher education. Therefore, the current study results will add to the literature regarding the influence of blended learning on students' academic performance in higher education.

- The Ministry of Higher Education in UAE has as an explicit goal the desire to update university teaching means and strategies in accordance with the demands of the twenty-first century. In this way, it will help contribute to the stated goals of the Ministry of Higher Education in UAE. It will also help to promote the quality of teaching in other countries too. Ultimately, the study will enhance understanding of the strengths and weaknesses of blended learning, and its applicability in various contexts.

- Faculty members for the statistics course Faculty in Middle Eastern universities will gain a blueprint for using mixed learning to improve student success by teaching statistics classes in new ways.

- The study results could be of interest to academics at universities by providing them with suggestions for the employment of a blended learning methodology. 


\section{$2 \quad$ Methodology}

\subsection{Study participants}

The participants for the present study comprised 268 students registered on a statistics course, which is a required course for all Ajman University students. They were divided into two groups: 135 students in the experimental group and 133 students in the control group. Figures 2 illustrates the demographics of the experimental group participants of a statistics course taught by blended learning, while the control group studied the same subjects by traditional learning methods. Therefore, the experimental group was taught by blended learning in 15 weeks, while the control group was taught by traditional learning in the same period. Figure 2 shows the distribution of the experimental group students based on gender, by college, and by academic year.

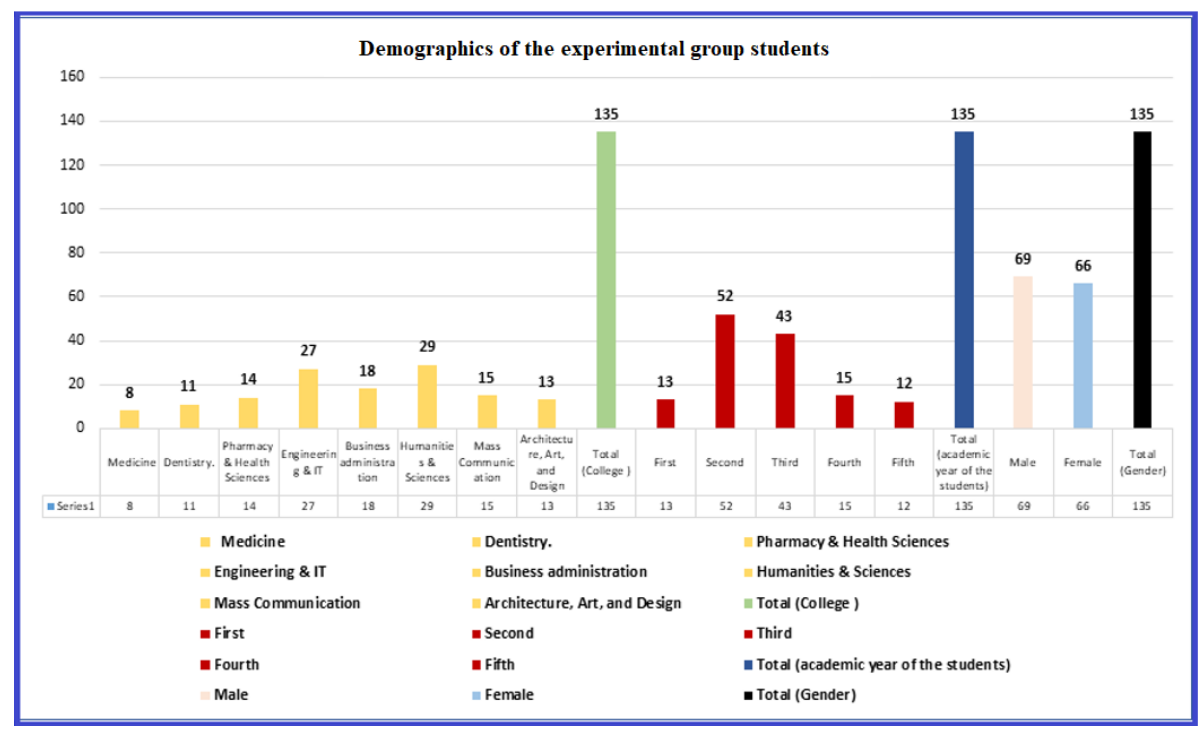

Fig. 2. Demographics of the experimental group students.

\section{$2.2 \quad$ The approach of study}

The quasi-experimental research design was employed for its suitability to the purpose of the study. In the current study, the researchers employed two groups of students (135experimental group students and a control group of 133 subjects) for an achievement test on the statistics course topics. The same topics of the statistics course were given to the students in the controlling group by the traditional teaching method, while the experimental group was given the topics of the statistics by blended learning. The design of the study is illustrated as shown in Figure 3. In another sense, similar topics were given to the students in both groups for a similar period (15 weeks) in the first semester of 2019/2020. Teaching subjects are illustrated in Table 1: 


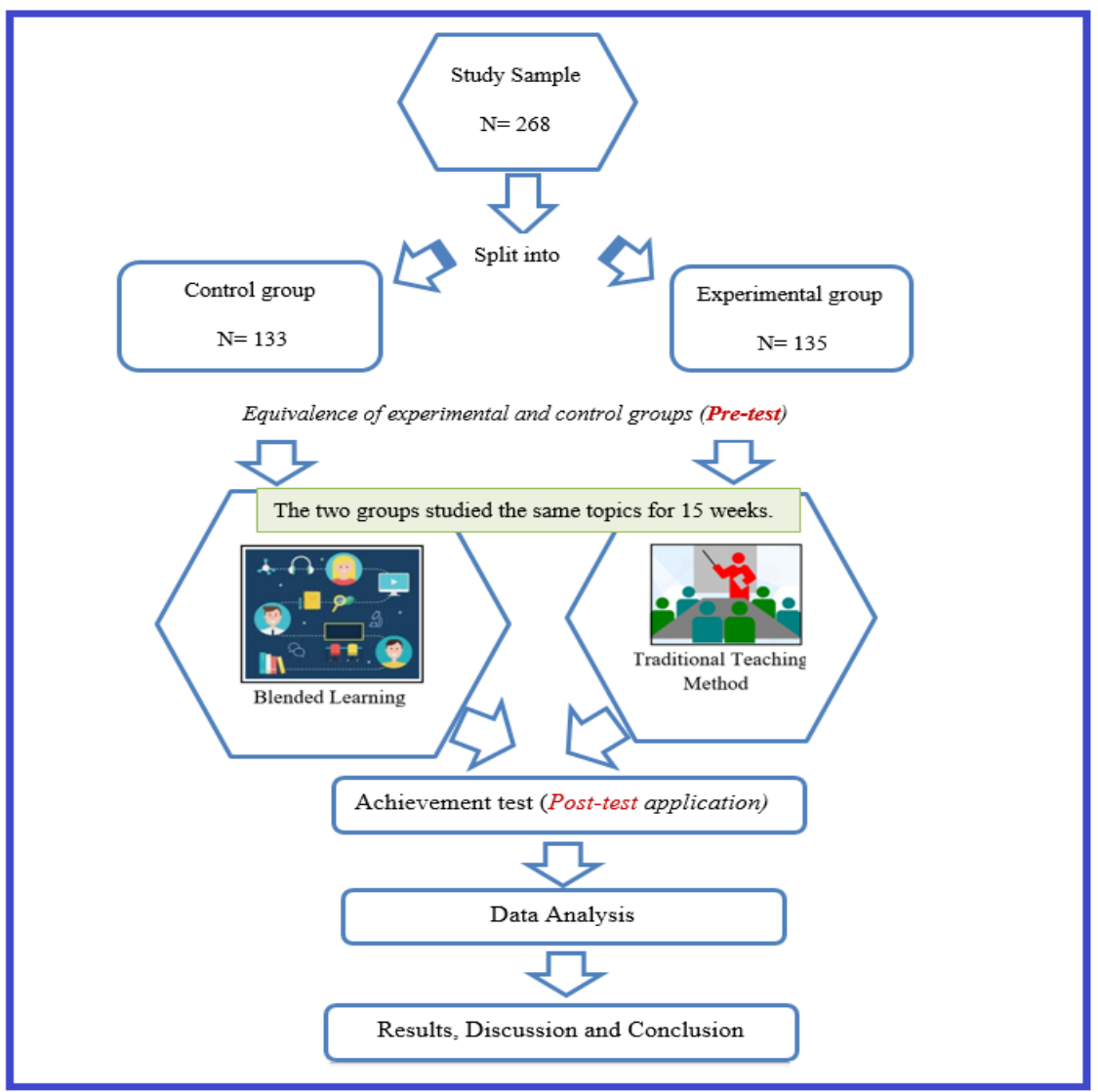

Fig. 3. The study design (source: authors' design).

Table 1. The learning topics of the statistics course [40].

\begin{tabular}{|c|l|}
\hline Week & \multicolumn{1}{|c|}{ Topics } \\
\hline 1 & Introduction to descriptive statistics \\
\hline 2 & Frequency distribution and interpretation of graphical presentation of data \\
\hline 3 & Cumulative distributions: Cumulative frequency tables and curves \\
\hline 4 & Data summarization; finding central tendency, position, and variation measures \\
\hline 5 & Exploratory data analysis: Box-whiskers plots and their uses \\
\hline 6 & Definition of probability and some related concepts \\
\hline 7 & Probability rules, total probability, and Bayes' theorem \\
\hline 8 & Random variables and probability distributions \\
\hline 9 & Discrete probability distributions \\
\hline 10 & Continuous probability distributions \\
\hline 11 & Central limit theorem and sampling distributions \\
\hline 12 & Point estimation of parameters \\
\hline 13 & Confidence interval based on a single sample and sample size \\
\hline 14 & Hypothesis testing: the test of a population mean based on a single sample \\
\hline 15 & Introduction to linear regression and correlation \\
\hline
\end{tabular}




\subsection{The tools of the study}

The researchers reviewed previous studies and literature associated to the title of the research $[10,9,41]$.

The design of the achievement test: The researchers in this work set a performance test for the investigation of the effect of blended learning on student academic accomplishment in the statistics course. Bloom's cognitive domain taxonomy was used to create the exam[42-45]. Moreover, for this exam, a specification table was developed (see Table 2). The test had a total of 20 multiple-choice questions in its final version. Each question received one point for any correct answer and zero points to any wrong answer. The maximum score could be 20 , and the test lasts for 90 minutes, every question requires the student to make calculations to reach a solution.

Table 2. Properties for testing the topics.

\begin{tabular}{|c|c|c|c|c|c|}
\hline Topics & $\begin{array}{l}\text { No. of } \\
\text { lessons }\end{array}$ & $\begin{array}{l}\text { The rela- } \\
\text { tive } \\
\text { weight of } \\
\text { topics }\end{array}$ & $\begin{array}{c}\text { Lower } \\
\text { thinking } \\
\text { Q }\end{array}$ & \begin{tabular}{|l|} 
Thinking \\
Questions \\
\& Critical \\
Thinking \\
Questions \\
\end{tabular} & Total Q \\
\hline - Introduction to descriptive statistics. & 2 & $7.14 \%$ & 1 & - & 1 \\
\hline \multicolumn{6}{|l|}{$\begin{array}{l}\text { - Frequency distribution and interpretation of } \\
\text { graphical presentation of data. }\end{array}$} \\
\hline $\begin{array}{l}\text { - Cumulative distributions: cumulative fre- } \\
\text { quency tables and curves. }\end{array}$ & 6 & $21.43 \%$ & 4 & 2 & 6 \\
\hline \multicolumn{6}{|l|}{$\begin{array}{l}\text { - Data summarization; finding central tenden- } \\
\text { cy, position, and variation measures. }\end{array}$} \\
\hline - Exploratory data analysis: Box-whiskers plot. & 2 & $7.14 \%$ & 2 & - & 2 \\
\hline \multicolumn{6}{|l|}{ - Probability and some related concepts. } \\
\hline - Probability rules, total probability. & 6 & $21.43 \%$ & 4 & 2 & 6 \\
\hline \multicolumn{6}{|l|}{$\begin{array}{l}\text { - Random variables and probability distribu- } \\
\text { tions. }\end{array}$} \\
\hline \multicolumn{6}{|l|}{$\begin{array}{l}\text { - Binomial and the Poisson probability distri- } \\
\text { butions. }\end{array}$} \\
\hline - Normal probability distribution. & 4 & $14.29 \%$ & 1 & 1 & 2 \\
\hline \multicolumn{6}{|l|}{$\begin{array}{l}\text { - Central limit theorem and sampling distribu- } \\
\text { tions. }\end{array}$} \\
\hline - Point estimation of parameters. & 4 & $14.29 \%$ & 1 & 1 & 2 \\
\hline \multicolumn{6}{|l|}{ - Confidence interval. } \\
\hline $\begin{array}{l}\text { - Hypothesis testing: Introduction to linear } \\
\text { regression and correlation. }\end{array}$ & 4 & 14.295 & 0 & 1 & 1 \\
\hline Total & 28 & $100 \%$ & $13(65 \%)$ & $7(35 \%)$ & $20(100 \%)$ \\
\hline
\end{tabular}

Table 2 shows the specification table that included a two-way map to assist teachers in connecting their instructional goals, cognitive level of learning, and the length of the exam that should be used to determine each target. Each sub-topic was assigned a number that corresponded to the test's key topics how much time the teacher spent teaching the topics, or the relative weight of topics. Therefore, the purpose of the aim of the table of specifications is to ensure that the test is balanced and that the achievement realms being evaluated are identified, as well as to ensure that a con- 
sistent and representative sample of questions appears on the test. Table 2 shows that questions classified as lower-level thinking skills numbered 13 (63\%), while those classified as higher-level thinking skills numbered 7 (35\%), for a total of 20 achievement test questions.

Validity and reliability of achievement test: The test achievement was validated through introducing it to associates of the academic staff of educational bodies with $\mathrm{Ph} . \mathrm{D}$. and MA holders in the fields of teaching and learning techniques for assessment in its initial type. We discarded a couple of the questions and replaced them with those that were proposed and encouraged to enhance the validity of the test. Furthermore, the researchers used the test-retest method to attest to the reliability of the achievement test. We conducted the test on a sample other than that to be sampled for the primary study. After fortnights of the first examination, it was again reapplied to the same group of students. Consequently, the Pearson correlation coefficient is calculated among the twofold apps was calculated to be 0.817 , which is considered satisfactory for the objectives of the study.

\subsection{Experimental group equivalence to the control groups (Pre-test)}

Until applying blended learning, the researchers made use of a t-test for paralleling the outcomes of the pre-test of the statistic course topics for the verification of the equivalence of participants in the two classes tested. The results are as shown in Tables 3 and 4 :

Table 3. Pre-test scores mean and standard deviations for control and experimental groups.

\begin{tabular}{|l|c|c|c|}
\hline \multicolumn{1}{|c|}{ Group } & N & Mean & Std deviation (SD) \\
\hline Control & 133 & 11.72 & 1.82 \\
\hline Experimental & 135 & 11.52 & 1.816 \\
\hline
\end{tabular}

Table 4. T-test in the pre-test outcomes of both groups.

\begin{tabular}{|l|c|c|c|c|c|c|}
\hline & \multicolumn{2}{|c|}{ Levene's Test } & \multicolumn{4}{c|}{ t-test } \\
\hline & $\boldsymbol{F}$ & Sig. & $\boldsymbol{t}$ & $\boldsymbol{d} \boldsymbol{f}$ & Sig. (2-tailed) & Mean Difference \\
\hline Equal variances assumed & .075 & .784 & .915 & 266 & .361 & .2033 \\
\hline Equal variances not assumed & & & .915 & 265.903 & .361 & .2033 \\
\hline
\end{tabular}

The test is not important at a level of 0.05 , as seen in Table 4 , since the derived $p$ $(0.361)$ is larger than 0.05 . This demonstrates that there was no substantial dissimilarity between the two research groups before the implementation of the experimental protocol. Also, Table 3 shows that the means are appoximately similar in the two groups (experimental group $=11.52$, control group $=11.72$ ) . This is prior to performing the quasi-experimental designe to confirm the comparability of results. 


\subsection{Statistical processing methods}

The researchers analyzed the study results using the SPSS software packagesuch as descriptive analysis including average, frequency estimation, and standard deviation (SD). This is in addition to the independent sample evaluation (t-test) and one-way ANOVA and LSD tests.

\subsection{Ethical considerations}

On February 4, 2020, the Research Ethics Committee / Deanship of Graduate Studies and Research of Ajman University (Reference number: H-F-H-2020-Jan-23) accepted this thesis (Reference number: H-F-H-2020-Jan-23)

\section{$3 \quad$ Findings}

\subsection{Findings of the study relative to RQ 1 .}

RQ1 was "Is there a significant difference among the control and experimental group students in their mean scores on the post-test?" The researchers calculated the variance among the post-test score means of experimental and control groups. Moreover, the study employed a T-test for dual independent models as in Tables 5 and 6 .

Table 5. Standard deviation and mean of post-test outcomes.

\begin{tabular}{|l|c|c|c|}
\hline \multicolumn{1}{|c|}{ Group } & N & Mean & SD \\
\hline Control & 133 & 12.91 & 1.67 \\
\hline Experimental & 135 & 17.67 & 1.57 \\
\hline
\end{tabular}

Table 5 shows the results that indicate blended learning improves comprehension of the topics taught on the statistical course, with the experimental group's grades being better $(M=17.67, \mathrm{SD}=1.57)$ than those of the control group $(\mathrm{M}=12.91, \mathrm{SD}=$ 1.67).

Table 6. The T-test of the post-test of independent sample

\begin{tabular}{|l|c|c|c|c|c|c|}
\hline & \multicolumn{2}{|c|}{ Levene's test } & \multicolumn{4}{|c|}{ t-test } \\
\hline & $\boldsymbol{F}$ & Sig. & $\boldsymbol{T}$ & $\boldsymbol{d f}$ & $\begin{array}{c}\text { Sig. } \\
\text { (2-tailed) }\end{array}$ & $\begin{array}{c}\text { Mean } \\
\text { Difference }\end{array}$ \\
\hline Equal variances presumed & .587 & .444 & 24.063 & 266 & 0.000 & 4.7643 \\
\hline Equal variances not assumed & & & 24.053 & 264.593 & 0.000 & 4.7643 \\
\hline
\end{tabular}

Provided that the p-value $(0.000)$ is less than 0.05 , as seen in Table 6 , there are important discrepancies at the significance level of 0.05 , implying a significant difference between the two groups, in favour of the study group. This means that, based on the findings of the T-test, it is possible to infer that the use of blended learning was 
beneficial for the experimental group students' understanding of the topics of the statistical course.

\subsection{Findings of the study relative to $\mathrm{RQ} 2$}

RQ2 was "Does the academic performance of experimental group students, who learned the information through blended learning, vary by gender, college, and academic year of the students?"

To answer the second research question, computing average scores and standard deviations, the study ran a t-test, one-way ANOVA, and LSD tests for detect theverage significance variance.

\section{- Gender}

T-test was used for the evaluation of the importance of the variances amongst the means of experimental group students' scores based on gender issues such as the use of blended learning, as shown in Table 7.

Table 7. Standard deviations and Mean scores according to "gender."

\begin{tabular}{|l|c|c|c|c|c|c|}
\hline \multicolumn{1}{|c|}{ Gender } & N & Mean & SD & df & T. Value & Sig. (tailed) \\
\cline { 1 - 5 } Female & 66 & 17.38 & 1.34 & 133 & 1.992 & 0.048 \\
\cline { 1 - 5 } Male & 69 & 16.86 & 1.68 & 128.967 & & \\
\hline
\end{tabular}

Table 7 shows the detected $p$ is $(0.048)$ which is less than 0.05 . Thus, the test is treated to be significant at the level of 0.05 , suggesting a significant difference among the mean scores for men and women, in favor of females.

- College

Table 8 explains the results of the one-way ANOVA test according to this measure.

Table 8. ANOVA test of "college."

\begin{tabular}{|l|l|c|c|c|c|c|}
\hline & & Sum of squares & Df & Mean square & F & Sig. (tailed) \\
\hline \multirow{2}{*}{$\begin{array}{l}\text { Student college } \\
\text { variable }\end{array}$} & In between groups & 28.804 & 7 & 4.115 & & \multirow{3}{*}{093} \\
\cline { 2 - 5 } & In groups & 290.529 & 127 & 2.288 & \multirow{2}{*}{0.799} & .093 \\
\cline { 2 - 5 } & Total & 319.333 & 134 & & & \\
\hline
\end{tabular}

- When $\mathrm{p}$ is 0.093 , higher than the statistical significance level required, the results clearly show no statistically significant differences in the academic performance of experimental group students indicated along with the variable of college, as seen in Table 8. (0.05).

- Academic year

Table 9 illustrates the resulting outcomes of a one-way ANOVA test based on "academic year." 
Table 9. One-way ANOVA test for variable "academic year."

\begin{tabular}{|c|c|c|c|c|c|c|}
\hline & & Sum of squares & Df & Mean square & $\mathbf{F}$ & Sig. (tailed) \\
\hline \multirow{3}{*}{\begin{tabular}{|l|} 
Variable of \\
student academ- \\
ic year
\end{tabular}} & Between Groups & 27.058 & 4 & 6.765 & \multirow{3}{*}{3.009} & \multirow{3}{*}{.021} \\
\hline & Within Groups & 292.275 & 130 & 2.248 & & \\
\hline & Total & 319.333 & 134 & & & \\
\hline
\end{tabular}

When $\mathrm{p}$ is 0.021 , fewer than the statistical significance threshold, the results show clearly statistically significant variations in the outcome of the experimental group who studied using blended learning based on "academic year", as seen in Table 9. (0.05). The LSD test was employed for the succeeding analyses to determine the source of the variations. Table 10 summarizes the findings.

Table 10. LSD test findings for variable "academic year."

\begin{tabular}{|c|c|c|c|}
\hline (I) student's Academic year & (J) student's Academic year & Mean difference (I-J) & Sig. \\
\hline \multirow{4}{*}{ First } & Second & -.635 & .175 \\
\hline & Third & -.578 & .226 \\
\hline & Fourth & $-1.528-*$ & .008 \\
\hline & Fifth & .288 & .632 \\
\hline \multirow{4}{*}{ Second } & First & .635 & .175 \\
\hline & Third & .057 & .854 \\
\hline & Fourth & $-.894-*$ & .044 \\
\hline & Fifth & .923 & .057 \\
\hline \multirow{4}{*}{ Third } & First & .578 & .226 \\
\hline & Second & -.057 & .854 \\
\hline & Fourth & $-.950-*$ & .036 \\
\hline & Fifth & .866 & .079 \\
\hline \multirow{4}{*}{ Fourth } & First & $1.528 *$ & .008 \\
\hline & Second & $.894 *$ & .044 \\
\hline & Third & $.950 *$ & .036 \\
\hline & Fifth & $1.817 *$ & .002 \\
\hline \multirow{4}{*}{ Fifth } & First & -.288 & .632 \\
\hline & Second & -.923 & .057 \\
\hline & Third & -.866 & .079 \\
\hline & Fourth & $-1.817-*$ & .002 \\
\hline
\end{tabular}

The findings shown in Tab.10 clarify that the source related to discrepancies in student's academic performance of the experimental group that practiced learning by blended learning according to academic year in their fourth academic year students.

\section{Discussion}

The first research question focused on whether in the post-test; there is a large gap in mean scores amongst students of the control and experimental groups. Findings showed that There was a substantial disparity amongst the experimental and control groups in favor of those in the experimental community that used mixed learning to 
study statistics topics. Students in the study group scored 17.67 on average, paralleled to 12.91 for students in the control group as indicated in Table 5. Furthermore, Table 6 shows that the p-value $(0.000)$ is lower than 0.05 , implying there are statistically significant differences level of 0.05 , indicating that it is considerable between both groups of students surveyed. This suggests that the experimental community students' interpretation of the statistics course topics improved as a result of using blended learning. This can be due to the benefits of using a mixed learning application in the classroom, such as accessibility, addressing students' expectations, and taking into account individual variation. Moreover, the findings could be because of blended learning allows straight communication in the classroom by using digital networking tools includinf laptops and the internet, as well as multimedia and blogs relevant to the lesson topics. Such facilities provide more realistic instructional environments as well as an engaging atmosphere that encourages students to participate more actively in the educational process. Furthermore, another study conducted by [46]where the aim was to see how blended learning affected German Jordanian University students' outcomes and aspiration of learning English. The findings showed statistically substantial variations in the outcomes of the control and expeirrmntal groups. This means the study group outperformed the control subjects. These results are concordant to those of previous research studies that confirmed that blended learning improved the achievement and academic performance. For example, [29]verified the influential part of blended learning on the academic accomplishment of intermediate school students in the southwest part of Turkey. The resulting findings showed that the blended learning setting generated a significant difference in students' academic achievement, in favor of the experimental group. Likewise, [31] measured the effect of strategy related to blended learning on learning progress and student's scientific procedure skills of a plant tissue culture course in the Universities Nigeria Medan. Its results indicate that When opposed to the traditional learning approach, the mixed learning strategy was substantially more successful in improving students' learning accomplishment and science process skills in the plant tissue culture course. Furthermore, the findings are concordant to those of [47, 48], who compared the blended learning atmosphere to a conventional learning environment in order to assess students' academic success. The results indicated that the average scores of the final test grades of the experiment group students were better than those of the control group students. Furthermore, another study conducted by [46]was to see how blended learning affected German Jordanian University students' progress and aims of learning English. The results showed that the study group outperformed the control. Moreover, the study conducted by [32] this study aimed to see how a blended learning approach affected secondary school students' critical thinking, addressing the problem, skills of science process, and science achievement. The findings revealed that integrated learning has a significant impact on students' critical reasoning, problem-addressing, skills of science process, and academic achievement. Similar results have been obtained in many studies $[33-35,37,5]$. The results maintained the positive role of blended learning on students' academic achievement. They also mentioned the importance of blended learning in terms of increasing enthusiasm and fostering optimistic attitudes toward mathematics, statistics, and science learning. This research has confirmed that mixed learn- 
ing increased students' motivation to study and that they developed positive roles for learning maths and science as a result of mixed learning. The other research inquiry focused on determining whether the academic performance of the study sample educated by blended learning varied by sex, faculty, and student's academic year. Our Results illustrated in Tables $(7,8,9$, and 10) illustrated that individuals of the experimental group are diverse based on the variable of gender (in favor of females), and based upon the variable of students' academic year (in favour of students in their fourth academic year). However, there were no statistically significant variances between students based on "college". This may be because female students are more committed and disciplined in following instructions, and have higher motivation to learn than do male students. For example, female students display interest and prompt responses to homework and assignments and study hard for exams. Though, the study results did not corroborate the results of the trial implemented by [39] regarding the influence of mixed learning on students' achievement on mathematical and statistical courses. The results illustrated that blended learning did not appear to have a little significant effect on differences in post-test scores among both groups the experimental and the control one. However, some limitations should be acknowledged. First, the size of the sample was constrained by that only 268 students were registered on the statistics term. Second, since blended learning is related to technology, there is a limitation with regards to computer and internet skills of both teachers and students of the experimental group, because students will face difficulty in accessing the course material. Thus, the researchers implemented this study with adequate technical support. In light of the aforementioned limitations, the study presents a range of academic consequences for next furture works to study the effect of blended learning upon students' academic performance:

- There is a necessity for additional empirical and expressive research to discover the advantages and hardships of carrying out blended learning in the process of learning and teaching.

- Analyses of the most active aspects of blended learning are needed to see how they can help students improve inspiration, commitment, and academic success.

- This study plays a part in the literature concerning the use of blended learning for learning scientific courses such as statistics topics course.

- To carry out similar studies dealing with the influence of using blended learning on other variables, such as motivation, engagement, readiness to learn, critical thinking, and multiple intelligences as well as in a variety of disciplines and applications.

It indicates that higher education establishments are interested in teaching by emerging media techniques such as blended learning rather than conventional teaching strategies would solve the issue of low student motivation and commitment in educational institutions. 


\section{Conclusion}

Higher education is a stage in which the development of students enables them to obtain the knowledge and skills required to meet the desires of the labor market. The United Arab Emirates has become focused on and concerned with the quality of education at all levels as an urgent priority to promote development. UAE higher education institutions are currently focusing on developing learning strategies and integrating technology and the internet into learning and instruction processes. The extension of electronic learning and using mixed learning and its prototypes in processes of teaching and learning are among the most significant aspects of this. This paper is designed to probe the impact of blended learning upon students' academic accomplishment in a statistics course at Ajman University. The findings showed that the use of integrated learning has a positive effect on students' academic success in a statistics course, according to this report. The data analysis revealed statistical differences between the experimental and the control groups' post-test scores, favoring the experimental group. Furthermore, the results illustrated that the scores of the experimental group members differed based gender (in favor of females), and academic year (in favor of those in the fourth academic year). However, no statistically significant difference was found among the students according to the variable of the college in which they studied.

\section{Delimitations of Study}

- Subject limits: Both concepts from the statistics course given to students during the $1^{\text {st }}$ term of the 2019/2020 academic year were included in the paper.

- Human limits: The sample was students enrolled in a statistics course at Ajman University UAE.

- Spatial limits: Ajman University in the UAE.

- Time limits: First semester of the academic year (2019/2020).

\section{$7 \quad$ References}

[1] F. Idris, Z. Hassan, A. Ya'acob, S. K. Gill, and N. A Awal, "The role of education in shaping youth's national identity," Procedia-Social and Behavioral Sciences, vol. 59, pp. 443450, 2012. https://doi.org/10.1016/j.sbspro.2012.09.299

[2] L. Davies, "Teaching about conflict through citizenship education," International Journal of Citizenship and Teacher Education, vol. 1, no. 2, pp. 17-34, 2005.

[3] K. Ayse, "An online social constructivist tool: A secondary school experience in the developing world," Turkish Online Journal of Distance Education, vol. 9, no. 3, pp. 87-98, 2008.

[4] N. S. Alseelawi, E. K. Adnan, H. T. Hazim, H. Alrikabi, and K. Nasser, "Design and Implementation of an E-learning Platform Using N-Tier Architecture," international Journal of Interactive Mobile Technologies, vol. 14, no. 6, pp. 171-185, 2020. https://doi.org/10.3991/ijim.v14i06.14005 
[5] M. B. Yilmaz and F. Orhan, "Pre-Service English Teachers in Blended Learning Environment in Respect to Their Learning Approaches," Turkish Online Journal of Educational Technology-TOJET, vol. 9, no. 1, pp. 157-164, 2010.

[6] H. Maccoun, "The effect of using blended learning on the achievement of students and information retention of fifth graders in the biology course," J. Fac. Educ, vol. 22, no. 95, pp. 209-240, 2016.

[7] A. Salah. R. S. Khairy, S. M. M. Najeeb, and H. ALRikabi, "Credit Card Fraud Detection Using Fuzzy Rough Nearest Neighbor and Sequential Minimal Optimization with Logistic Regression," International Journal of Interactive Mobile Technologies, vol. 15, no. 5, 2021. https://doi.org/10.3991/ijim.v15i05.17173

[8] M. G. Alzahrani and J. M. O'Toole, "The Impact of Internet Experience and Attitude on Student Preference for Blended Learning," Journal of Curriculum and Teaching, vol. 6, no. 1, pp. 65-78, 2017. https://doi.org/10.5430/jct.v6n1p65

[9] N. R. Alsalhi, M. E. Eltahir, and S. S. Al-Qatawneh, "The effect of blended learning on the achievement of ninth grade students in science and their attitudes towards its use," Heliyon, vol. 5, no. 9, p. e02424, 2019. https://doi.org/10.1016/j.heliyon.2019.e02424

[10] S. Al-Qatawneh, M. E. Eltahir, and N. R. Alsalhi, "The effect of blended learning on the achievement of HDE students in the methods of teaching Arabic language course and their attitudes towards its use at Ajman University: A case study," Education and Information Technologies, pp. 1-27, 2019. https://doi.org/10.1007/s10639-019-10046-w

[11] C. R. Graham, "Emerging practice and research in blended learning," Handbook of distance education, vol. 3, pp. 333-350, 2013.

[12] N. K. Elfaki, I. Abdulraheem, and R. Abdulrahim, "Impact of E-learning vs Traditional Learning on Student's Performance and Attitude," International Medical Journal, vol. 24, no. 03 , p. 225, 2019.

[13] P. Moskal, C. Dziuban, and J. Hartman, "Blended learning: A dangerous idea?," The Internet and Higher Education, vol. 18, pp. 15-23, 2013. https://doi.org/10.1016/j.iheduc. 2012. $\underline{12.001}$

[14] C. Dziuban, C. R. Graham, P. D. Moskal, A. Norberg, and N. Sicilia, "Blended learning: the new normal and emerging technologies," International journal of educational technology in Higher education, vol. 15, no. 1, pp. 1-16, 2018. https://doi.org/10.1186/s41239017-0087-5

[15] B. M. Wright, "Blended learning: Student perception of face-to-face and online EFL lessons," Indonesian journal of applied linguistics, vol. 7, no. 1, pp. 64-71, 2017. https://doi.org/10.17509/ijal.v7i1.6859

[16] A. Salah, Rihab Salah Khairy, Haider TH. Salim ALRikabi2, "The Detection of Counterfeit Banknotes Using Ensemble Learning Techniques of AdaBoost and Voting," International Journal of Intelligent Engineering and Systems, vol. 14, no. 1, pp. 326-339, 2021. https://doi.org/10.22266/ijies2021.0228.31

[17] M. Saritepeci and H. Cakir, "The effect of blended learning environments on student motivation and student engagement: A study on social studies course," Egitim ve Bilim, vol. 40, no. 177, 2015. https://doi.org/10.15390/eb.2015.2592

[18] F. Shang and C.-Y. Liu, "Blended learning in medical physiology improves nursing students' study efficiency," Advances in physiology education, vol. 42, no. 4, pp. 711-717, 2018. https://doi.org/10.1152/advan.00021.2018

[19] M. Yeou, "An investigation of students' acceptance of Moodle in a blended learning setting using technology acceptance model," Journal of Educational Technology Systems, vol. 44, no. 3, pp. 300-318, 2016. https://doi.org/10.1177/0047239515618464 
[20] S. Trapp, "Blended learning concepts-A short overview," in Innovative Approaches for Learning and Knowledge Sharing, EC-TEL 2006 Workshops Proceedings, 2006, pp. 2835: Citeseer.

[21] H. M. Huang, "Toward constructivism for adult learners in online learning environments," British journal of educational technology, vol. 33, no. 1, pp. 27-37, 2002. https://doi.org/ $\underline{10.1111 / 1467-8535.00236}$

[22] T. I. Oweis, "Effects of using a blended learning method on students' achievement and motivation to learn English in Jordan: A pilot case study," Education research internation$a l$, vol. 2018, 2018. https://doi.org/10.1155/2018/7425924

[23] N. Tongchai, "Impact of self-regulation and open learner model on learning achievement in blended learning environment," International Journal of Information and Education Technology, vol. 6, no. 5, p. 343, 2016. https://doi.org/10.7763/ijiet.2016.v6.711

[24] D.Al-Malah, H. H. Jinah, and Haider Th. Salim, "Enhancement of educational services by using the internet of things applications for talent and intelligent schools," Periodicals of Engineering and Natural Sciences (PEN), vol. 8, no. 4, pp. 2358-2366, 2020.

[25] N. A. Hussein, H. A. Naman, M. Al-dabag, and H. Salim Alrikabi, "Encryption System for Hiding Information Based on Internet of Things," International Journal of Interactive Mobile Technologies (iJIM), vol. 15, no. 2, 2021. https://doi.org/10.3991/ijim.v15i02.19869

[26] R. Rafiola, P. Setyosari, C. Radjah, and M.. Ramli, "The Effect of Learning Motivation, Self-Efficacy, and Blended Learning on Students' Achievement in The Industrial Revolution 4.0," International Journal of Emerging Technologies in Learning (iJET), vol. 15, no. 8, pp. 71-82, 2020. https://doi.org/10.3991/ijet.v15i08.12525

[27] D. Khalid , S. I. Hamed, and H. ALRikabi, "The Interactive Role Using the Mozabook Digital Education Application and its Effect on Enhancing the Performance of eLearning," International Journal of Emerging Technologies in Learning (iJET), vol. 15, no. 20, pp. 21-41, 2020. https://doi.org/10.3991/ijet.v15i20.17101

[28] S. J. Seage, and M. Türegün, "The Effects of Blended Learning on STEM Achievement of Elementary School Students," International Journal of Research in Education and Science, vol. 6, no. 1, pp. 133-140, 2020. https://doi.org/10.46328/ijres.v6i1.728

[29] V. K. Ceylan and A. E. Kesici, "Effect of blended learning to academic achievement," Journal of Human Sciences, vol. 14, no. 1, pp. 308-320, 2017. https://doi.org/10.14687/jhs . $\mathrm{v} 14 \mathrm{i} 1.4141$

[30] B. H. Majeed, L. F. Jawad, and H.Salim, "The Impact of CATs on Mathematical Thinking and Logical Thinking Among Fourth-Class Scientific Students," International Journal of Emerging Technologies in Learning (iJET), vol. 16, no. 10, pp. 194-211,2021. https://doi.org/10.3991/ijet.v16i10.22515

[31] F. Harahap, N. E. A. Nasution, and B. Manurung, "The Effect of Blended Learning on Student's Learning Achievement and Science Process Skills in Plant Tissue Culture Course," International Journal of Instruction, vol. 12, no. 1, pp. 521-538, 2019. https://doi.org/10.29333/iji.2019.12134a

[32] G. Mondal, P. Majumder, and M. Mandal, "Effect of blended learning strategy for secondary school science students," International Journal of Research and Analytical Reviews, vol. 6, no. 1, pp. 381-387, 2019.

[33] M. A. OCAK and A. D. TOPAL, "A blended learning approach to motivation of medical students taking anatomy class," International Journal on New Trends in Education \& their Implications (IJONTE), vol. 5, no. 3, 2014.

[34] R. Mabuan and G. Ebron, "A blended learning approach to teaching writing: using e-mail in the ESL classroom," ed, 2016. 
[35] K. P. Maguire, Professional development in a blended e-learning environment for middle school mathematics teachers. University of Toronto, 2005.

[36] J. Mula, "Effects of e-blended instruction on grade 10 students' performance and attitude towards geometry," Trece Martires City National High School, 2015.

[37] S. J. Seage and M. Türegün, "The Effects of Blended Learning on STEM Achievement of Elementary School Students," International Journal of Research in Education and Science, vol. 6, no. 1, pp. 133-140, 2020. https://doi.org/10.46328/ijres.v6i1.728

[38] B. H. Majeed, L. F. Jawad, H. Alrikabi, "Tactical Thinking and its Relationship with Solving Mathematical Problems Among Mathematics Department Students," International Journal of Emerging Technologies in Learning (iJET), vol. 16, no. 9, 2021. https://doi.org/10.3991/ijet.v16i09.22203

[39] R. Yusoff, N. H. M. Noh, and S. Yusoff, "A blended learning module for a course in statistics," 2017.

[40] A. G. Bluman, Elementary statistics: A step by step approach. McGraw-Hill Higher Education New York, NY, 2009.

[41] M. Oliver and K. Trigwell, "Can 'blended learning'be redeemed?," E-learning and Digital Media, vol. 2, no. 1, pp. 17-26, 2005. https://doi.org/10.2304/elea.2005.2.1.17

[42] S. Birlik, "Taxonomy of the cognitive domain: an example of architectural education program," Procedia-Social and Behavioral Sciences, vol. 174, pp. 3272-3277, 2015. https://doi.org/10.1016/j.sbspro.2015.01.993

[43] A.-M. Brady, "Assessment of learning with multiple-choice questions," Nurse Education in Practice, vol. 5, no. 4, pp. 238-242, 2005. https://doi.org/10.1016/j.nepr.2004.12.005

[44] V. J. Gamble, "The effectiveness of blended learning for the employee," Fielding Graduate University, 2005.

[45] D. Lalima and K. L. Dangwal, "Blended learning: An innovative approach," Universal Journal of Educational Research, vol. 5, no. 1, pp. 129-136, 2017. https://doi.org/10.13189 /ujer.2017.050116

[46] T. Oweis, "Effects of using a blended learning method on students' achievement and motivation to learn English in Jordan: A pilot case study," Education research international vol. 2018, 2018. https://doi.org/10.1155/2018/7425924

[47] A. Kundu, T. Bej, and M. Rice, "Time to engage: Implementing math and literacy blended learning routines in an Indian elementary classroom," Education and Information Technologies, vol. 26, no. 1, pp. 1201-1220, 2021. https://doi.org/10.1007/s10639-020-10306-0

[48] D. Abdul-Rahman, I. Aljazaery, H. Salim, and H. A Mutar, "Cloud Computing and its Impact on Online Education," IOP Conference Series: Materials Science and Engineering, vol. 1094, p. 012024, 2021. https://doi.org/10.1088/1757-899x/1094/1/012024

\section{Authors}

Dr. Najeh Rajeh Ibrahim Al Salhi is a Researcher of Educational Science, Education Department, College of Humanities and Sciences at Ajman University. Also, at Nonlinear Dynamics Research Center (NDRC), Ajman University, Ajman, UAE. He holds a Ph.D. degree in Curriculum and Methods of Science (Chemistry). Dr. Alsalhi Began His Career as A Public-School Science and Chemistry Teacher. He Also Served as Science \& chemistry Supervisor in The Ministry of Education, Jordan. He Also Served within the team's pivotal as an expert of science for authoring and computing Jordanian science curriculum Under the supervision of the Ministry of Educa- 
tion, Jordan Training Technology Group "Rubicon". He is a Member of the Training beginner Teachers group in Jordan. He received his B.Sc. in Science "chemistry" from Al Yarmouk University in 1994 and his Master Degree in Education Science from The University of Juba, Sudan in 2001, and his Doctorate in Curriculum and Methods of Teaching Science "Chemistry" from the University of Omdurman - Sudan, 2013. Al Salhi Published Most of his Papers at Professional International Conferences and Scientific Journals.

Dr. Nadia Ouakli, holder of a PhD in Statistics from Sorbonne Sciences University, Paris in 1986, is a faculty member teaching statistics courses at Nonlinear Dynamics Research Center (NDRC) Ajman University Ajman, UAE since 2000. Her research interests are in Statistical modeling, Statistics and online Education. She is coauthor of the book "Methodes Statistiques a l'usage des etudiants du tronc biomedical."- Office des publication Universitaires Alger".

Hanine Bou Antoun is a lecturer of Statistics at the Unit of General Studies, Nonlinear Dynamics Research Center (NDRC), Ajman University, Ajman, UAE. Previously, she was a lecturer of basic and advanced business Statistics courses at LIU and CNAM universities in Lebanon. In addition, she is an expert in data analysis and data processing with more than 7 years of professional experience in the marketing research field. She holds a Master's Degree in Statistics from Lebanese University.

Dr. Atef Abdelkader, Assistant Prof. in physics, the Head of Math and Science department, Nonlinear Dynamics Research Center (NDRC), Ajman University, Ajman, UAE. He got his PhD in Physics, from The Queen's University (U.K.). His $\mathrm{PhD}$ project concerned the physics of $2 \mathrm{D}$ foam. This work was characterized by innovative experimental approaches and careful analysis. It set new standards in the field and settled two separate controversies in a rather final way. He also found novel and quite unexpected phenomena, which are still only partly understood. He has an interest in a number of areas like Optics-Lasers, Spectroscopy, and Optical System Technology - Any area where science is applied.

Layth Abdul Razak M. Al Jumaili is a lecturer of Statistics at the Unit of General Studies, Nonlinear Dynamics Research Center (NDRC), Ajman University, Ajman, UAE. He has taught different courses in statistics at the college level for over 25 years. Some of his favorite subjects to teach are regression analysis, application of statistical methodology, and statistical computing. Additionally, he have taught the technology part of statistics by utilizing statistical soft wares (i.e. Minitab and SPSS).

Dr. Mohd Elmagzoub Eltahir is an Associate Professor of Educational Technology, Education Department, College of Humanities and Sciences at Nonlinear Dynamics Research Center (NDRC), Ajman University, Ajman, UAE. He holds a PhD in Education Technology. Dr. Eltahir Began His Career as A Public School IT Teacher. He Also Served as IT Educational Supervisor in The Ministry of Education, U.A.E. He Received his B.Sc. in Computer Science from U.A.E University in 1993, and his Master Degree in Education Technology from The University of Southern Queensland-Australia in 2003, and his Doctorate in Education Technology from Khartoum University - Sudan in 2007. Dr. Eltahir Performs Scientific Research in ELearning, Educational Technology, and Multimedia in Education and Has Presented and Published Most of his Papers at Professional International Conferences and Sci- 
entific Journals. He Teaches Educational Courses at The Undergraduate and Postgraduate Programs. Furthermore, He has Significant Consultancy Experience in The Fields of Using Technology in Education, in Different Schools in U.A.E. He Received the Sharjah Award for Excellence in Education in 2009.

Dr. Sami Suleiman Hamid AL Qatawneh is an Associate Professor of Educational, Education Department, College of Humanities and Sciences at Nonlinear Dynamics Research Center (NDRC), Ajman University, Ajman, UAE. He Holds a PhD degree in Curriculum and Methods of Teaching Arabic. Dr. AL Qatawneh Began His Career as A Public School Arabic language Teacher. He Also Served as Arabic language Educational Supervisor in The Ministry of Education, Jordan. He Also Served as Lecturer in the Mutah University in Jordan. He Received his Doctorate in Curriculum and Methods of Teaching the Arabic Language from Amman Arab University Jordan in 2007. AL Qatawneh Published Most of his Papers at Professional International Conferences and Scientific Journals. He Teaches Educational Courses at The Undergraduate and Postgraduate Programs. Furthermore, He has Significant Consultancy Experience in The Fields of teaching and instruction.

Article submitted 2021-05-06. Resubmitted 2021-05-28. Final acceptance 2021-05-30. Final version published as submitted by the authors. 